\title{
Extending Life: From Stem Cells to Gene Therapy
}

Judson Gary ${ }^{1}$ and Genard Hajdini ${ }^{*}$

${ }^{1}$ Regent University School of Global Leadership \& Entrepreneurship, USA

${ }^{2}$ Department of Health Information, Communication and Technology, Rruga: Aleksander Moisiu, Albania, USA

*Corresponding author: Genard Hajdini, Department of Health Information, Communication and Technology, Institute of Public Health in Albania,Rruga: Aleksander Moisiu, Albania, USA, Tel: 0035544506438; E-mail: genahaj@regent.edu

Rec date: October 15, 2015; Acc date: April 13, 2016; Pub date: April 29, 2016

Copyright: (c) 2016 Gary J. This is an open-access article distributed under the terms of the Creative Commons Attribution License, which permits unrestricted use, distribution, and reproduction in any medium, provided the original author and source are credited

\begin{abstract}
This paper deals with stem cell boogies and longevity market on the DNA gene therapy business. In Dr. James Canton's book, The Extreme Future, the author mentions several health cures and enhancement ideas that stemcell treatments may offer in twenty years: 1) New organs, including hearts and lungs; 2) New bone growth for legs, arms, and backs; 3) New sensory functions and optic nerves to restore eyesight; 4) New cancer treatments; 5) New nerves to heal muscles and to restore movement; 6) New cells to offset the aging brain. Since, James Watson and Francis Crick discovered and published the book The Double Helix (1968), DNA; the health sciences have had an incredible boom and growth. DNA is the basics of life's inheritance, and most of the modern health innovations are due to its understanding. "Life-extension treatments, from genetic vaccines and designer DNA 'surgery' to smart drugs and neuro-medical devices, will augment health, improving intelligence, and maximizing beauty" [1].
\end{abstract}

A clear picture of what is ahead is also given also by James Martin a rocket scientist in his book: The Meaning of the 21st Century, on gene therapy or "genetically modified humans," as well as shedding light on our other topic of "the magic of stem cells." This report is written for Departmental Heads of the Institute of Public Health (IPH) in Albania, who are in position of developing future healthcare policies, and supporting development programs of "adult stem cells" and "genetic engineering" cures for population at large. The interested investors will be the healthcare insurance companies, public health officials, and tertiary hospital caregivers in the healthcare industry, which will join in a Public-Private-Partnership (PPP) to achieve the desired results to cure damaged tissues of the human body and heal genetically inherited disease by gene splicing and insertion, also known as transplanting genes.

\section{Introduction}

Longevity Medicine is the way to the future [1]. James Martin, a futurist thinker and scientist, says: "More workable forms of human enhancement are likely to come from prosthetics, nanotechnology, regenerative medicine drugs that affect the brain and electronic devices that enhance human capability" [2]. He calls this movement trans humanism, while Canton names it human enhancement. A more holistic Future Map of healthcare as described in Annexes A and B should have these components: Wealth, Boomers, Personal Medicine, Genomics, and Longevity; all converging as customers and market drivers [3]. In The Extreme Future, Canton considers "biotech, nanotech, neurotech and IT/networks" to be building blocks for the innovation economy. The convergent of Nano-Bio-Info-Neuro technology is one of biggest yet to come in the next 20 to 30 years. Forecasters are already surmising how this might affect our bodies and the health industry 30 to 50 years from now (Discovery Channel 2007). Given this possibility, how big will the human enhancement industry become? The purpose of this paper is to focus in two aspects of healthcare development: 1) stem cell research and its potential for curing disease and becoming business opportunity; and 2) gene therapy and its curative and material gains from it.

This paper presents these two business ideas to the Institute of Public Health (IPH) in Albania for consideration as it develops future healthcare policy in the sciences. In order to be able to use the stem cell research to regenerate damaged tissue in the human body organs, one has to understand the curative power of these miracle cells. Also, instead of suffering with inherited disease one can learn the power of manipulating genes through restriction enzymes to cut DNA into manageable pieces into sticky ends, which are single-chain "tails" of DNA and so start by transplanting genes [4].

\section{Stem cells}

Longevity is linked with regenerative medicine, which in turn is enhanced by the process of stem cell research. A stem cell is formed when a human sperm first fertilizes an egg and what is more important is the fact that it has the ability to transform into any type of cell in the human body. After four days of fertilization, a hollow sphere of cells forms a 'blastocyst.' The stem cells in the blastocyst are not yet specialized for particular functions yet, therefore can be extracted and saved at low temperatures with the potential of developing into any of the 200 different mature cell types in our bodies heart, muscles, liver, brain cells and so on Martin [2]. This trait is known as "pluripotent" embryonic stem cells. This issue has ethical implications, due to the belief that life starts at conception.

Scientists have found another way that is acceptable from all and is not controversial in a religious setting as well: adult stem cells. These exist in a mature body and relate to human birth. These adult stem cells are known as "multipotent" [2]. Pablo Rubinstein who initiated the procedure of collecting these adult stem cells from the blood of a woman's umbilical cord when she has a baby is a practice that in most of the world, "these stem cells are washed down the drain" not as in the New York Blood Center, where they are stored and could later grow 
into tissues needed later in life [2]. Stem-cell research can lead to the replacement of damaged tissues and organs for many body parts that have been warn-out.

On the other hand dealing with the second point of this paper defines "Treating a genetic disorder by introducing a gene into a cell or by correcting a gene defect in a cell's genome is called gene therapy" [4]. A lot of questions arise, such as "What does it mean for the future of healthcare if 90 percent of consumers want tests to reveal their genetic destiny"? What will the impact of personal wealth be on provision of healthcare? [3].

\section{Gene therapy}

Defective genes can cause horrifying human diseases. Huntington's disease is one of them. It runs in the family and it is inherited by a single bad gene. Symptoms of madness appear at 40 to 50 years old, which they are passed in the brain of the children by this time. Scientists could modify the genetic makeup by slicing the gene through an enzyme and maybe by inserting a healthy gene instead. It is known that "Gene therapy is well suited for treating genetic disorders that result from a deficiency of a single enzyme or protein" [4].

Human Genome Project began in 1990 and by 1996 it had analyzed out of the main goal of determining the nucleotide sequence of the whole human DNA genome as found by Watson and Crick in 1956 around three billion nucleotide pairs, or 100,000 genes to map the exact location of every gene on each one of the 23 chromosomes [4]. Genes can be sliced and diced through recombinant-DNA technology that is available today. Germline modification will pass the altered gene to the next generation without truly knowing its side effects [2]. However, a 24th artificial chromosome could be created and inserted in the embryo together with the other 23 natural chromosomes and pass along in all the other cells of that person by having the option of switching it on and off, to insure that it is not a "germline engineering" because it is "no inheritable". A controlling code could determine where and when the particular genes are expressed. "Germline modification is much simpler than somatic modification because it can be done with an embryo, and when a baby grows from the embryo, all of its cells contain the change. This avoids the difficulty of having to modify 10 trillion cells in a grown person" says James Martin.

Therefore for 2015, it is proposed that "germline engineering" starts as a first option in the form of screening the parent DNA genetic map or human genome before they have a F1 offspring generation. In this way the parents will know what genetic makeup they have and how they can take away some of the "bad" genes, so they are not transmitted to the next generation, such as Huntington, Cystic Fibrosis, Muscular Dystrophy, Sickle Cell Anemia, Parkinson, Alzheimer, and many other diseases (Figures 1 and 2).

Latter by 2025 , the scientists can start to build the 24th artificial chromosome that will be able to be switched on and off according to the demand of the parents for their children that will be able to command the downloading of the genetic information that would be needed to correct the bad genetic makeup of the children. This will be achieved by isolating the gene, than producing recombinant DNA, which is the combination of DNA from two or more sources, later by cloning the DNA in a host organism that receives recombinant DNA called a transgenic organism. This is seen in the case of insulin gene production where expression of cloned genes becomes possible [4].

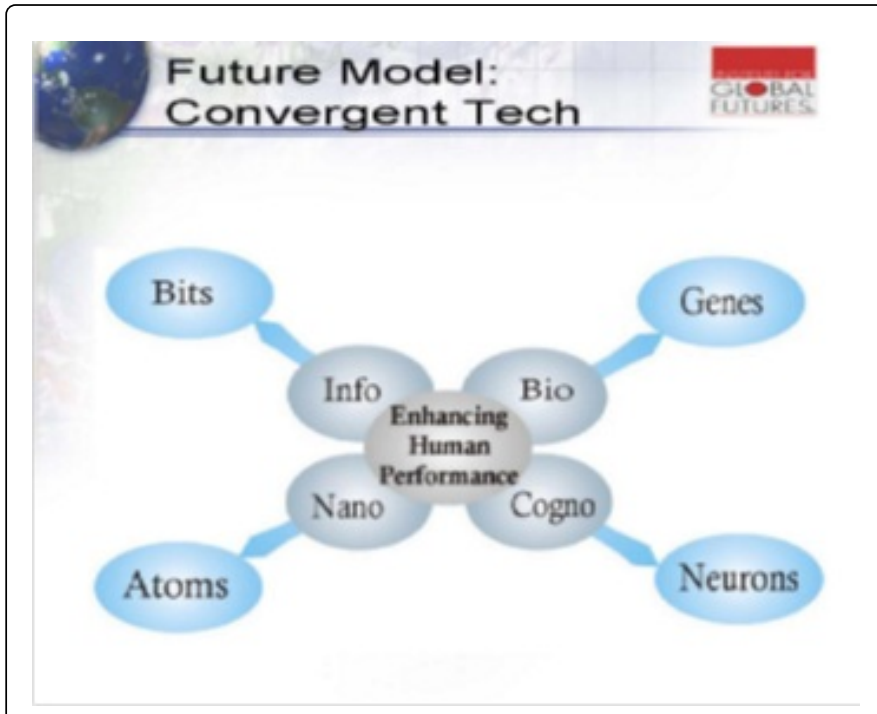

Figure 1: Future map of convergent model.

\section{Trend Analysis: Stem Cells and Gene Therapy}

The world we live in has become a place of great scientific development, but unfortunately many are suffering a lot of disease from damaged organ tissues in the liver, heart, brain, etc to many more genetic disorders that are prevalent and inherited from one generation to the next. There is an increasing trend of chronic disease from cardiovascular to brain tumors, internal organ cancers, and higher frequency of mental health diseases, lack of insulin production and higher incidence of diabetes, to many more inherited disease that come as lack of certain proteins, shut down of biochemical pathways, and many other biological disorders that give some bad scenarios to human lives.

\section{Demographic trends}

\section{Causes}

Both countries in U.S. and Albania we are experiencing an increase of aging population and higher prevalence of chronic disease and damaged organ tissues. Obesity and hypertension with heart problems, unhealthy lifestyle with colon-liver-pancreas-stomach cancers, aging population's brain disease, radiation from the sun, thinner ozone layer and skin cancers, Chlorofluorocarbons toxic cancerous materials together with PVC-s, toxic asbestos materials, smoking and lung cancers. Increase in inherited disease: blood, mental, lack of proteins (insulin), reproductive growth problems, skeletal muscular system diseases, etc.

\section{Effects}

Higher healthcare costs to cover for the incurred expenses, higher number of sick people versus per capita of healthy people. Higher risk of insurance coverage to become more discriminative and expensive than it is currently. STEEP driving forces (Social, Technological, Economic, Environmental, Political) are among some of the most predetermine factors in the further development of products/services in the years to come. 


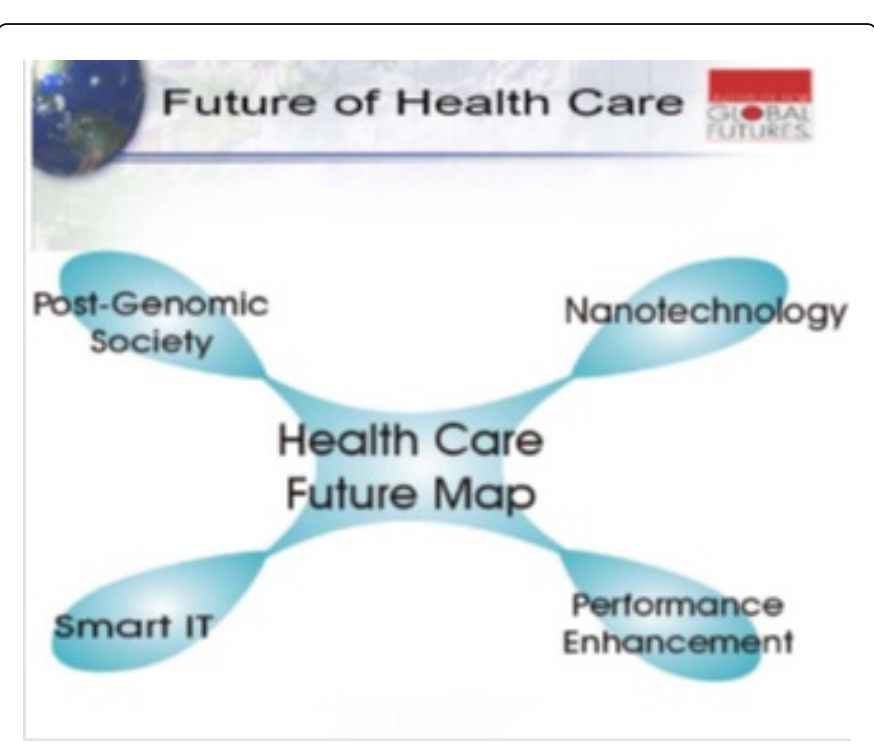

Figure 2: Future map of health care model.

\section{Social trends}

\section{Causes}

Advocacy, promotion, education and media can safeguard the health and promote the usefulness of stem cell research and genetic engineering.

\section{Effects}

People in both countries especially in U.S. play a better role in advocacy, promotion, education and use of media. Also, the young immigrant population that is constantly coming to U.S. helps because this is a "brain gain" process, while in Albania all of the above are week with the exception of media, in addition Albania is experiencing a "brain drain," where most of the young people and educated workforce are living the country to immigrate in higher standard of living countries.

\section{Technological Trend}

\section{Causes}

New drugs, medical treatments will be produced through stem cells and genetic vaccines. This will lead to ever increasing demand in the market.

\section{Effects}

People will want to have stem cells to replace damaged cells so they can extend life. Also young parents will desire children to be born without defects or genetic disorders. So, their pressure will push technology to produce products and services: 1) New organs, including hearts and lungs; 2) New bone growth for legs, arms, and backs; 3) New sensory functions and optic nerves to restore eyesight; 4) New cancer treatments; 5) New nerves to heal muscles and to restore movement; 6) New cells to offset the aging brain [3].

\section{Economic trends}

\section{Causes}

Rising living standards, longer life, food, shelter, longevity, refurbished body parts, etc.

\section{Effects}

Rise of healthcare costs, bankruptcy of insurance market, out-ofpocket pay or high fee for service for stem cell surgery, or transplantation of healthy genes instead of bad genes. Extension of lifespan and longevity will cost a lot in medical drugs and treatments.

\section{Environmental Trends: Monitoring}

"The monitoring activity for issues in Categories II and III concentrates on environmental shifts (these shifts might include, but not be limited to, changes in the direction of events, trends, and driving forces) and corporate shifts (these shifts might include, but not be limited to, changes in organizational policies, products, services, marketing strategies, or operating procedures) that could turn them into high priority, Category I issues needing analysis and management" [5]. Both environmental and corporate shifts are important in this scanning and monitoring process.

\section{Causes}

Environmental shifts in both countries have to do with better sanitation, sewage treatment, water and air quality, less radioactive material, toxic and radiation, etc.

\section{Effects}

Need of less smoking in public places especially in Albania, garbage collection, treatment of fresh water, sewage treatment, etc. In U.S. cleaner Water and Air Pollution Act with Kyoto Protocol and Global Warming problem and climate changes, need to take place.

\section{Political trend}

\section{Causes}

Politically both countries will be faced with mitigation issues and ethical issues pending the legislation to pass in favor or not of the advancement of research. One observed throughout this paper that science of economics and biology are normative sciences used for analysis, measuring, quantifying, and deriving conclusions on observations. They are not equipped to answer the aesthetic question of value, belief, or religion. And since as long as the people will have a system of values, beliefs, culture, or religion, they will not allow the economics or biology to determine what is right from wrong for them. One can clearly see that the ethical values will determine the making of science or any other public policy. Now the question is what is right from wrong? Dr. Mark Sagoff, an ethics philosopher, would argue that which is true from false is right from wrong [6]. How can we know truth from false in a system that is full of relativism, where all you believe to be true is true to you, but it may not be true to someone else? This is the point when each of us has the freedom, in democratic countries but not in totalitarian dictatorship regimes, to choose a system of moral ethical values, in which we believe to be true. 
Page 4 of 4

\section{Effects}

Government will spend a lot of time and money in investing through IPH and NIH in these new programs of stem cells and gene therapy. They will also have to provide with the appropriate legislation for these to happen. Bruce Reichenbach and V. Elving Anderson in their book On Behalf of God, give a comprehensive biology ethics based on the Judeo-Christian belief system that could be a moral guideline on how to develop a responsible research methods and auditing issues proper way. The question is whether the government will take into account any moral connotation that might rise in the verge of the innovation and business ventures that will bring millions of dollars to healthcare industry, where Canton [3] says that a human genome mapping and a genetic engineering effort costs approximately over $\$ 200,000$ (two hundred thousand dollars) per person.

\section{Ethical implications}

People in Albania and U.S. will strive due to their desire for better treatment of their tissues and genetic disease to do legal and illegal operations and cures. Many of them will not have the necessary finances to cover these expensive services. What will the outcome be, and is the government going to cover the costs through national or private insurance schemes? Is medicine going to be nationalized or privatized? Is primary care and public health care going to be a public externality together with public education or private entity of the "greedy"? Are today's financial crises a telling on what can men's moral sends us? The government needs to play a more decisive role on what is ethical and lawful from what is not [7-10].

\section{Conclusion}

Many people worry about the use of personal genetic information. Some think that the insurance companies will use this type of information to "discriminate against individuals who are genetically susceptible to a disease" [4]. Those that have inherited disease that are expensive to treat; it will be denied the insurance coverage as a case of predisposed condition. The information from the Human Genome Project will involve how the society should use the DNA sequencing privacy issues. The questions will arise on the use of stem cell research, but less on "adult stem cells" and more so on "gene therapy" but still less on the use of switching on and off "artificial chromosome" that will install all the genetic "drivers and utilities" necessary for upgrade of the human life. This is enhancement, regenerative medicine that leads to longevity twigging and tempering with prolonging of life span on Earth.

My two services: 1) adult stem cell research; and 2) gene therapy could be developed after the initial stages of R\&D at both IPH and NIH could become patent and each of the viable data banks for stem cells could be stored in a big depository that would be used in case of emergencies when hospital reserves would run low due to their use on patients who need organ tissue repairs. The same thing is done with the patents of issuing every malfunction gene for every curable one, for each single source gene disease. Collaboration among both scientific institutes is possible through trainings and exchange visits of researcher teams. Governments of both countries should have a state budget, fees for services, donor funds, trainings, wills, etc. to finance the research. The beneficiaries would be the people most in need of these services the sick from tissue organs and the ones with genetic disorders that run in the family. Let us hope that the cost of these future services will come to be useful and manageable for everyone who desires these services for a better life and future. Life goes on...!

\section{References}

1. Canton J (2006) The extreme future: The top trends that will reshape the world for the next 5, 10, and 20 years. New York: Dutton.

2. Martin J (2006) The meaning of the 21st century: A vital blueprint for ensuring our future. Great Britain: Eden Project Books

3. Canton J (2003) Navigating the Extreme Future, World Future Society Presentation, San Francisco, CA.

4. Holt, Rinehart, Winston (2002) Modern Biology. Austin: Harcourt.

5. Des Jardins, Joseph R (1997) Environmental Ethics. 2nd Edn. Washington: Wadsworth.

6. Ashley WL, James LM (1995) Anticipatory Management: 10 power tools for achieving excellence into the 21st century. Leesburg, Virginia: Issue Action Publications.

7. http://www.globalfuturist.com

8. Reichenbach RB, Anderson E (1995) On Behalf of God. Michigan: Eerdmans.

9. Sagoff M (1999) Environmental Economics and the Conflation of Value and Benefit. Maryland 4:10.

10. Watson JD (1968) The double helix: A personal account of the discovery of the structure of DNA. New York: Atheneum. 